\title{
Effect of food additives on the quality of white shrimp (Litopenaeus vannamei)
}

\author{
${ }^{1}$ Nor Salasiah, M. and ${ }^{2}$ Jirarat, T. \\ ${ }^{1}$ Food Technology Research Centre, Malaysia Agricultural Research Development Institute, 43400 \\ Serdang, Selangor, Malaysia \\ ${ }^{2}$ Department of Food Technology, Faculty of Science, Chulalongkorn University, Bangkok 10330, Thailand
}

\begin{abstract}
Article history:
Received: 30 May 2018

Received in revised form: 4

September 2018

Accepted: 4 September 2018

Available Online: 6

November 2018

Keywords:

White Shrimp,

Sodium Tripolyphosphate

(STPP),

Microbial Transglutaminase

(MTGase),

Sodium Bicarbonate,

Water Holding Capacity.
\end{abstract}

DOI:

https://doi.org/10.26656/fr.2017.2(6).114

\begin{abstract}
The effects of three additives: sodium tripolyphosphate (STPP), sodium bicarbonate $\left(\mathrm{NaHCO}_{3}\right)$ and microbial transglutaminase (MTGase) with the addition of $2 \%$ sodium chloride $(\mathrm{NaCl})$ at different concentrations $(2,5$ and 8\%) and times $(10,30$ and 60 minutes) at $4 \pm 2{ }^{\circ} \mathrm{C}$ on the quality of frozen-thawed white shrimp (Litopenaeus vannamei) were studied. In average, compared to control, different concentrations and immersion times of three additives with $2 \% \mathrm{NaCl}$ significantly $(\mathrm{p}<0.05)$ affected the water holding capacity (WHC), cooking weight loss (CL), weight gain (WG), moisture content (MC) and microbial load (TVC) of white shrimps. The combined effect of $2 \% \mathrm{NaCl}$ with all additives showed synergistic effect on reducing CL, increased WHC and yielded a good quality of frozen-thawed white shrimps. Treatment by immersions of shrimp in 5\% MTGase with $2 \% \mathrm{NaCl}$ for 30 minutes improved the quality as compared to control. Furthermore, these treatments increased weight gain (16\%) and WHC up to $94 \%$, lowered CL to $10 \%$ and TVC $1.78 \log$ cycle.
\end{abstract}

\section{Introduction}

The white shrimps Litopenaeus vannamei is one of the dominant economically-important products of Thailand. Frozen shrimp export generating export revenue for Thailand economy. Changes in texture of thawed muscle are a negative economic factor. Processing of frozen shrimp products encompasses a wide array of pre and post-treatments to create higher value addition. Shrimp muscle increases in firmness by heat processing and becomes too firm, lack of juiciness and unpalatable when heating temperature exceeds $70^{\circ} \mathrm{C}$ (Mizuta et al., 1999). There is a possibility of increasing the quality of frozen-thawed shrimp by using food additives.

Sodium tripolyphosphate (STPP) has been widely accepted as an additive in seafood and the most popular choice to improve water holding capacity, texture, stabilise colour and reduce cooking loss. STPP is limited to a maximum $0.5 \mathrm{~g} / 100 \mathrm{~g}$ sample in the final product according to Europe, Canadian and Brazilian regulations for seafood products (Gonçalves and Ribeiro, 2008). The use of non-phosphate ingredients such as sodium bicarbonate $\left(\mathrm{NaHCO}_{3}\right)$ and microbial transglutaminase (MTGase) have an advantage over using phosphate. MTGase is an enzyme with the ability to cross-link proteins through covalent bonds. It improves solubility, water holding capacity and texture quality of fish products (Motoki and Seguro, 1998) MTGase increase breaking force of white shrimp gel and lowered the expressible moisture content with increasing MTGase amount (Tammatinnaa et al., 2007). Sodium bicarbonate is a chemical compound that able to increase the weight gain of fresh shrimp up to $10 \%$ and lowered CL to $20 \%$ by dipping at $8 \%$ concentration (Henderson et al., 1990).

This study analyzed the effects of food additive treatments with different treatment conditions (food additive concentration and immersion time) on the quality of frozen-thawed white shrimp to maximize the water holding capacity (WHC), increase weight gain (WG) and moisture content (MC), improve the texture, reduce cooking loss (CL) and total viable count (TVC) of the shrimp. The treatment with non-phosphate additive could be an alternative way to improve the quality of frozen shrimp.

\section{Materials and methods}

\subsection{Materials}

White shrimps (90-100 count $/ \mathrm{kg}$ ) were procured 
from Charoean Pokphand Food Public Company, Thailand. The untreated white shrimps were dressed in headless, peeled and deveined style and frozen prior to transportation and treatments. The untreated frozen white shrimp were thawed in chill storage $\left(0-4^{\circ} \mathrm{C}\right)$ for overnight (12 hrs) before the treatments.

\subsection{Food additives treatment}

The treatments were done using three additives: Sodium tripolyphosphate (STPP) with 2\% sodium chloride $(\mathrm{NaCl})$, Sodium bicarbonate $\left(\mathrm{NaHCO}_{3}\right)$ with $2 \%$ $\mathrm{NaCl}$ and Microbial transglutaminase (MTGase; Activa TG-HP $\left.{ }^{\circledR}\right)$ with $2 \% \mathrm{NaCl}$ at different concentrations $(2,5$ and $8 \% \mathrm{w} / \mathrm{w})$ and different immersion times $(10,30$ and 60 mins) at $4 \pm 2^{\circ} \mathrm{C}$ with 1:2 shrimp: brine solution ratio. The experiment was designed using $3^{3}$ factorial in Completely Randomized Design (CRD) with two replicates to analyze the effects of food additives immersion on the quality of white shrimp (Table 1). Food grade $\mathrm{NaCl}, \mathrm{NaHCO}_{3}$ and STPP was procured from CT Chemical Co., Ltd and MTGase (Activa ${ }^{\circledR}$ TGHP) was supplied by Ajinomoto Co. (Thailand) Ltd.

\subsection{Texture measurement}

Shear force determination was carried out at room temperature $\left(28 \pm 2^{\circ} \mathrm{C}\right)$. The shear force of samples was measured using texture analyser (Stable Micro System; TA-XT2 $i$, England) with a Warner-Bratzler blade. The operating parameter used was the cross-head speed of 10 $\mathrm{mm} / \mathrm{s}$. The maximum force to cut at the centre of the second abdominal segment about $1 \mathrm{~mm}$ at $45^{\circ}$ angle of the shrimp was recorded as the shear force (Mallick et al., 2010). The measurement was replicated ten times for each sample.

\subsection{Water holding capacity (WHC)}

WHC was characterized by measuring the expressible moisture (EM). EM was determined using a modification of the filter paper press method (Schubring et al., 2003). The sliced samples were pressed between paired filter sheets (Schleicher and Schuell, $7 \times 7 \mathrm{~cm}$ ) and parallel plates using a texture analyser. A $25 \mathrm{~kg}$ load cell and a crosshead speed of $1.70 \mathrm{~mm} / \mathrm{s}$ were used. Samples were pressed to $75 \%$ deformation and held at that point for $15 \mathrm{~s}$. WHC was calculated as $\% \mathrm{WHC}=\{1$-[initial weight-final weight)/initial weight]\} $\mathrm{x} 100$ (DíazTenorio et al., 2007).

\subsection{Cooking weight loss (CL)}

The treated shrimp was cooked with hot water at $100 \pm 2^{\circ} \mathrm{C}$ for 5 mins with 1:5 shrimp: water ratio. CL was calculated based on the weight of the sample before and after cooking (Erdogdu et al., 2007). Equation used is shown as $\% \mathrm{CL}=(\mathrm{A}-\mathrm{B}) / \mathrm{A} \times 100$. Where $\mathrm{A}$ and $\mathrm{B}$ is the weight before and after cooking, respectively.

\subsection{Weight gain (WG)}

WG was calculated based on the weight of the sample before and after pre-treatment. \%WG equals (B$\mathrm{A}) / \mathrm{Ax} 100$. Where $\mathrm{A}$ and $\mathrm{B}$ is the weight before and after pre-treatment, respectively (AOAC, 2005).

\subsection{Moisture content (MC)}

Moisture content was determined by drying $10 \mathrm{~g}$ of the sample in air oven at $105^{\circ} \mathrm{C}$ for $5-12 \mathrm{hrs}$ to constant weight (AOAC, 2005).

\subsection{Microbiological analysis - total viable count (TVC)}

A total of twenty-five grams of food sample were diluted to $225 \mathrm{~mL}$ of sterile $0.1 \%$ peptone water and masticated using laboratory paddle blender (Stomacher ${ }^{\circledR}$ ). Serial dilutions were made and one $\mathrm{mL}$ of each appropriate dilution was pour plated using plate count agar (Merck), allowed to gel to cool and incubated at $37^{\circ} \mathrm{C}$ for $24-48 \mathrm{hrs}$ (McLandsborough, 2005).

\section{$2.9 \mathrm{pH}$ analysis}

The $\mathrm{pH}$ value was recorded using a $\mathrm{pH}$ meter Consort C860 (Consort, Turnhout, Belgium). Each measurement was replicated three times with two replicates. Thirty grams of shrimp was homogenized with $150 \mathrm{~mL}$ distilled water at sample to water ratio 1:5 (w/v) and allowed to dissolve for 2 mins before the analysis. The $\mathrm{pH}$ meter was calibrated with standard buffers of $\mathrm{pH} 4.0$ and 7.0 before the measurement (Siripongvutikorn et al., 2008).

\subsection{Colour analysis}

Colour of the raw and treated shrimps, the gravy (green curry) and the homogenized sample (marinated shrimp in green curry) were measured using a Chromameter CR-400 (Minolta, Osaka, Japan). The color was expressed in CIE Lab system $L^{*}, a^{*}$, and $b^{*}$ values, where $L^{*}$ denotes lightness on a $0-100$ scale from black to white, $\mathrm{a}^{*}(+)$ red or $(-)$ green and $\mathrm{b}^{*}(+)$ yellow or (-) blue (Schubring et al., 2003). This instrument was calibrated with white reference tiles $(\mathrm{Y}=93.5 ; x=$ $0.3132 ; y=0.3198$ ) before the analysis. The shrimp was placed on the white tray above the light sources and will be measured directly. Glass cell containing the green curry and homogenized sample of shrimp with green curry was placed above the light sources and $L^{*}, a^{*}, b^{*}$ values were then recorded. Five readings were done for each sample with two replicates (Mallick et al., 2010). 
Table 1. Pre-treatment using $3^{3}$ Factorial in Completely Randomized Design (CRD) of twenty-seven treatments.

\begin{tabular}{|c|c|c|c|c|c|}
\hline Std & Run & Block & $\begin{array}{c}\text { Factor } 1 \\
\% \text { Percentage }\end{array}$ & $\begin{array}{c}\text { Factor } 2 \\
\text { Time (mins) }\end{array}$ & $\begin{array}{c}\text { Factor } 3 \\
\text { Preservatives }\end{array}$ \\
\hline 41 & 1 & Block 1 & 8 & 10 & MTGASE \\
\hline 13 & 2 & Block 1 & 2 & 30 & STTP \\
\hline 7 & 3 & Block 1 & 2 & 20 & STTP \\
\hline 29 & 4 & Block 1 & 8 & 20 & sodium bicarbonate \\
\hline 35 & 5 & Block 1 & 8 & 30 & sodium bicarbonate \\
\hline 21 & 6 & Block 1 & 5 & 10 & sodium bicarbonate \\
\hline 1 & 7 & Block 1 & 2 & 10 & STTP \\
\hline 27 & 8 & Block 1 & 5 & 20 & sodium bicarbonate \\
\hline 33 & 9 & Block 1 & 5 & 30 & sodium bicarbonate \\
\hline 53 & 10 & Block 1 & 8 & 30 & MTGASE \\
\hline 45 & 11 & Block 1 & 5 & 20 & MTGASE \\
\hline 9 & 12 & Block 1 & 5 & 20 & STTP \\
\hline 49 & 13 & Block 1 & 2 & 30 & MTGASE \\
\hline 19 & 14 & Block 1 & 2 & 10 & sodium bicarbonate \\
\hline 23 & 15 & Block 1 & 8 & 10 & sodium bicarbonate \\
\hline 5 & 16 & Block 1 & 8 & 10 & STTP \\
\hline 43 & 17 & Block 1 & 2 & 20 & MTGASE \\
\hline 51 & 18 & Block 1 & 5 & 30 & MTGASE \\
\hline 17 & 19 & Block 1 & 8 & 30 & STTP \\
\hline 3 & 20 & Block 1 & 5 & 10 & STTP \\
\hline 15 & 21 & Block 1 & 5 & 30 & STTP \\
\hline 47 & 22 & Block 1 & 8 & 20 & MTGASE \\
\hline 31 & 23 & Block 1 & 2 & 30 & sodium bicarbonate \\
\hline 11 & 24 & Block 1 & 8 & 20 & STTP \\
\hline 25 & 25 & Block 1 & 2 & 20 & sodium bicarbonate \\
\hline 37 & 26 & Block 1 & 2 & 10 & MTGASE \\
\hline 39 & 27 & Block 1 & 5 & 10 & MTGASE \\
\hline 50 & 28 & Block 2 & 2 & 30 & MTGASE \\
\hline 28 & 29 & Block 2 & 5 & 20 & sodium bicarbonate \\
\hline 10 & 30 & Block 2 & 5 & 20 & STTP \\
\hline 8 & 31 & Block 2 & 2 & 20 & STTP \\
\hline 4 & 32 & Block 2 & 5 & 10 & STTP \\
\hline 54 & 33 & Block 2 & 8 & 30 & MTGASE \\
\hline 20 & 34 & Block 2 & 2 & 10 & sodium bicarbonate \\
\hline 12 & 35 & Block 2 & 8 & 20 & STTP \\
\hline 32 & 36 & Block 2 & 2 & 30 & sodium bicarbonate \\
\hline 14 & 37 & Block 2 & 2 & 30 & STTP \\
\hline 46 & 38 & Block 2 & 5 & 20 & MTGASE \\
\hline 34 & 39 & Block 2 & 5 & 30 & sodium bicarbonate \\
\hline 44 & 40 & Block 2 & 2 & 20 & MTGASE \\
\hline 22 & 41 & Block 2 & 5 & 10 & sodium bicarbonate \\
\hline 36 & 42 & Block 2 & 8 & 30 & sodium bicarbonate \\
\hline 52 & 43 & Block 2 & 5 & 30 & MTGASE \\
\hline 26 & 44 & Block 2 & 2 & 20 & sodium bicarbonate \\
\hline 16 & 45 & Block 2 & 5 & 30 & STTP \\
\hline 48 & 46 & Block 2 & 8 & 20 & MTGASE \\
\hline 38 & 47 & Block 2 & 2 & 10 & MTGASE \\
\hline 40 & 48 & Block 2 & 5 & 10 & MTGASE \\
\hline 6 & 49 & Block 2 & 8 & 10 & STTP \\
\hline 42 & 50 & Block 2 & 8 & 10 & MTGASE \\
\hline 18 & 51 & Block 2 & 8 & 30 & STTP \\
\hline 24 & 52 & Block 2 & 8 & 10 & sodium bicarbonate \\
\hline 30 & 53 & Block 2 & 8 & 20 & sodium bicarbonate \\
\hline 2 & 54 & Block 2 & 2 & 10 & STTP \\
\hline
\end{tabular}

min: minutes. The pre-treatment was done using the same raw material for every batch in the same replicates, the pre-treatment was replicated two times.

Factor A : Percentage of preservative : $a 1=2 \%, a 2=5 \%$ and $a 3=8 \%$

Factor B : Time immersion: $\mathrm{b} 1=10 \mathrm{mins}, \mathrm{b} 2=30 \mathrm{mins}$ and $\mathrm{b} 3=60 \mathrm{mins}$

Factor $\mathrm{C}$ : Additives: $\mathrm{C} 1=\mathrm{STPP}$ and $2 \% \mathrm{NaCl}, \mathrm{C} 2=\mathrm{NaHCO}_{3}$ (sodium bicarbonate) and $2 \% \mathrm{NaCl}$ and $\mathrm{C} 3=\mathrm{MTGase}\left(\right.$ Activa ${ }^{\circledR} \mathrm{TG}-\mathrm{HP}$ ) and $2 \%$ $\mathrm{NaCl}$.

Control: Un-treated shrimps. 


\section{Results}

Effects of concentration and immersion time of each type of additives on physical properties and microbiology analysis are shown in Tables 2 and 3. On average, the results showed that both concentration and immersion time had a significant effect $(p<0.05)$ for all attributes of the treated shrimp when compared to control. Among the three additives with $2 \% \mathrm{NaCl}$, MTGase gave better results for all studied parameters. Immersion white shrimp in 5\% MTGase for 30 mins increased the WG (15.65\%), MC (84.00\%) and WHC (94.50\%), lowered CL to $10.15 \%$ and reduced TVC for about $1.78 \log$ cycle. The shear force value for this sample was not significantly different with control $(p>0.05)$. For $\mathrm{NaHCO}_{3}$ and STPP, when compared within their own group, $5 \%$ of concentration and 60 mins immersion reduced TVC and $\mathrm{CL}$, increased $\mathrm{WG}$ and MC.

\subsection{Weight gain (WG)}

Overall, WG was increased with increasing concentration of the additives with $2 \% \mathrm{NaCl}$ and immersion time $(p<0.05)$ up to $15.74 \%$ compared with control. In contrast, some treated shrimps (treatments no. $7-8,12,15-18,22-23$ and 25-27) did not show an increase in WG as the concentration and immersion time increased (Table 2). Higher concentration of the additives could lead to yield loss due to excessive solubilisation or disruption of protein filaments that increases expressible moisture and reduces water holding capacity.

\subsection{Texture}

The shear force value for treated shrimp was not significantly different from control (Table 2). When toughening of the treated shrimp was reduced, firmness and juiciness increased, and the shrimp texture becomes more elastic (chewy). The shear force value was decreased when the moisture content was increased. The elastic texture was dominant and provided fibrous characteristic on the sample treated with MTGase $+2 \%$ $\mathrm{NaCl}$. Faithong et al. (2006) reported that the shrimp immersed in a higher concentration of phosphate (2-3\%) and salt $(2-3 \%)$ for 8 and $10 \mathrm{hrs}$ at $5{ }^{\circ} \mathrm{C}$ resulted in higher shear force.

According to physical observation, the texture of the raw shrimp muscle (control) was softer than the treated shrimp, but the shear force value for control was higher because of the ventral nerve code at below abdominal segment inside the shrimp meat. The ventral nerve code was toughed and stronger than the ventral nerve code in treated shrimp. This ventral nerve code usually was not removed by the manufacturer. The graph of the shear force was increased when the Warner-Bratzler blade cut at the ventral nerve code inside the shrimp meat and gave a higher value of the shear force.

Improvement of water holding capacity in treated shrimp with MTGase at $4^{\circ} \mathrm{C}$ resulted in a good texture of shrimp which reduced toughness (shear force range 15.35-18.09 N) and increased firmness, juiciness and gel -forming ability (elastic texture) that provided fibrous characteristic. Motoki and Seguro (1998) reported that the activity of MTGase was inactivated after heating to above $70^{\circ} \mathrm{C}$. This is due to the optimum temperature for enzymatic activity was $50^{\circ} \mathrm{C}$, and MTGase fully sustained its activity even at $50^{\circ} \mathrm{C}$ for 10 mins. On the other hand, it lost activity within a few minutes on heating to $70^{\circ} \mathrm{C}$. MTGase still expressed activity at $10^{\circ} \mathrm{C}$ and still retained some activity at temperatures just above the freezing point.

Electrophoretic pattern SDS-PAGE of white shrimp reported by Sriket et al. (2007) showed that myosin heavy chain (MHC) was the dominant protein component $(57-64 \%)$, actin was found as a second dominant protein. The actin and myosin (actomyosin) react as a substrate, gelled by an enzyme (MTGase) through the cross-linked protein and result in thermal stability of protein (Motoki and Seguro, 1998).

\subsection{Total viable count (TVC)}

The treatment with $5 \%$ MTGase $+2 \% \mathrm{NaCl}$ for 30 mins results in the lowest microbial load for only $2.92 \pm 0.01 \log \mathrm{CFU} / \mathrm{g}$ compared with the other treatments. This treatment lowers the microbial load for about $1.78 \mathrm{log}$ cycle compared with the control sample (4.70 log CFU/g) (Table 2). The result showed that only the samples treated with MTGase had a significant lower TVC value compared with control samples. This might be due to the $\mathrm{pH}$ value range from 8.17 to 11.15 (Table 2 ), which was not suitable for microbial growth. Carballo et al. (2006) reported that MTGase/caseinate $(1.5 \mathrm{~g} / 100$ g) using cold binding systems for restructured meat inhibited the rapid growth of bacteria.

\subsection{Cooking weight loss (CL)}

The lowest $\mathrm{CL}$ value was found in sample treated with $5 \%$ MTGase $+2 \% \mathrm{NaCl}$ for 30 minutes $(10.15 \%)$ that was much lower than the control sample which had $51.13 \%$ CL (Table 2). It was also found that treated shrimp had a lower CL when the concentration of the additives and immersion time was increased $(p \leq 0.05)$. Only the sample treated with $8 \%$ MTGase $+2 \% \mathrm{NaCl}$ for 60 mins and $2 \% \mathrm{STPP}+2 \% \mathrm{NaCl}$ for 30 and $60 \mathrm{mins}$ had a higher CL value as the immersion time increased. Treatments with longer immersion time reduced the water retention and increased water loss during cooking. 


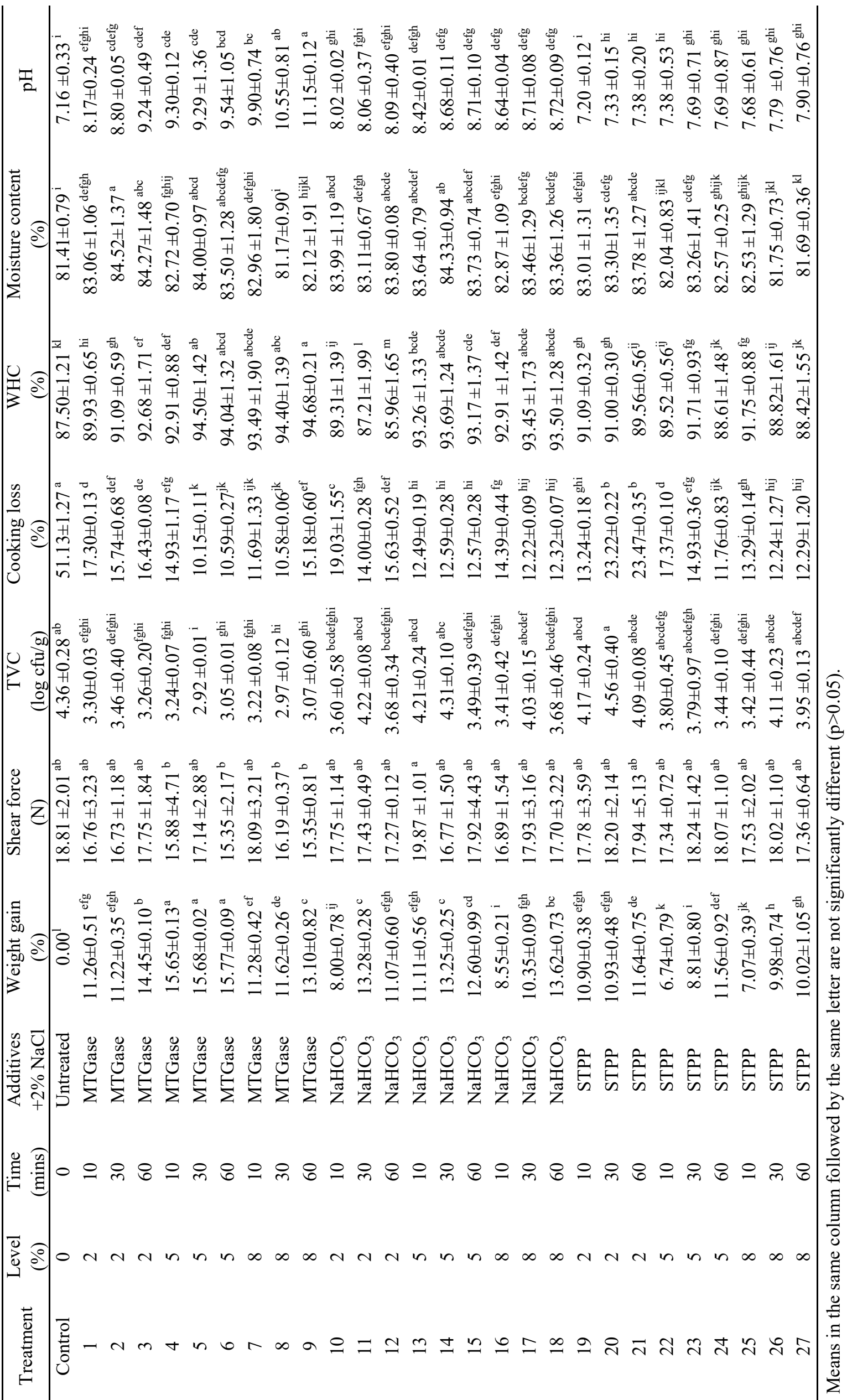


This may be due to an excessive solubilisation and disruption of protein filaments resulting an increase in CL value.

Benjakul et al. (2008) reported that the CL of black tiger shrimp and white shrimp increased sharply after being heated for a longer time for more than 0.5 to 3 mins $(p<0.05)$. Cooking loss of frozen fish products after thawing was reduced by a combination of MTGase in tumbling or injection of frozen fish products (Motoki and Seguro, 1998). Tammatinna et al. (2007) reported that more water retained in the gel network of white shrimp with the increasing MTGase (Activa ${ }^{\circledR}$ TG-K) amount added (0.2-0.8 unit/g sample).

Erdogdu et al. (2007) explained that cook losses were highly depending on the concentration and time of immersion in sodium tripolyphosphate (STPP) solution $(p<0.05)$. The diffused amount of STPP was around $0.25 \%$ in the meats dipped in the $2 \%$ STPP solution after 30 mins of dipping time which made $2 \%$ STPP not effective to reduce cook losses.

Faithong et al. (2006) reported that the combined effect of $2 \%$ STTP with $1-3 \%$ salt for 10 hours at $<5^{\circ} \mathrm{C}$ showed a synergistic effect on reducing cooking loss and increase raw weight gain of white shrimp $(\mathrm{p}<0.05)$ when compared with sample treated with only phosphate. There was no significant effect with tetrasodium pyrophosphate (TSPP) and sodium hexametaphosphate (SHMP) in reducing cooking weight loss.

\subsection{Water holding capacity (WHC)}

Overall, the WHC of treated shrimp was increased $(\mathrm{p} \leq 0.05)$ from $87.50 \%$ for the control sample up to $94.68 \%$ (Table 2). The result showed that when $\mathrm{pH}$ increased the WHC value was also increased (Table 2). Only three samples (treatment number 11, 24 and 27) did not show an increase in WHC compared with control ( $>00.05)$. For treatments with MTGase, the WHC was increased when the concentration and immersion time increased. Too much absorption of water will increase the muscle protein solubility and lowered the WHC.

Tammatinna et al. (2007) reported that lowered expressible moisture was noticeable with increasing MTGase (Activa ${ }^{\circledR}$ TG-K) amount added from 0.2 to 0.8 unit/g sample $(\mathrm{p}<0.05)$. For $\mathrm{NaHCO}_{3}$ and STPP at higher concentration and longer immersion time, the WHC did not increase. This is due to the absorption of too much water that increased the muscle protein solubility and thus, lowered WHC.

Pietrasik and Li-Chan (2002) reported that in cooked restructured meat products, gel firmness and waterholding capacity $(\mathrm{WHC})$ significantly $(\mathrm{p}<0.01)$ increased by the addition of $0.5 \%$ MTGase in high salt $(2 \%)$ compare to the sample without MTGase.

\subsection{Moisture content (MC)}

Compared with control, MC of treated shrimp was increased when the concentration and immersion time increased $(\mathrm{p} \leq 0.05)$. The MC increased from $81.41 \%$ (control) to $84.52 \%$ (Table 2). Only five samples (treatments number 8, 9, 22, 26 and 27) were not significantly different from control. Higher concentration and longer immersion time might cause protein denaturation and lower the moisture content. Faithong et al. (2006) reported that moisture content of the sample treated with $1-3 \%$ salt and $2 \%$ STPP for $10 \mathrm{hrs}$ at $<5^{\circ} \mathrm{C}$ was significantly lower than that of the control (without salt).

\section{7 pH analysis}

Treated shrimp with MTGase and $\mathrm{NaHCO}_{3}$ significantly increased the $\mathrm{pH}$ value of white shrimp up to 11.15 and 8.72 respectively (Table 2 ). The $\mathrm{pH}$ value was increased when the concentration of the additives and immersion time increased. For shrimp treated with $2 \% \mathrm{MTGase}+2 \% \mathrm{NaCl}$ for 10 mins, $2 \% \mathrm{NaHCO}_{3}$ for 10 , 30 and 60 mins and all treated shrimp using STPP $+2 \%$ $\mathrm{NaCl}$, the $\mathrm{pH}$ value was not significant different from control ( $p>0.05)$.

Ünal et al. (2004) reported that there were two diffusion mechanisms taking place. Where the meat samples naturally had high amounts of orthophosphates the compound diffuses into the solutions, while STPP diffuses into the meat samples. The STPP diffusion into the meat samples was relatively slower compared with the orthophosphate diffusion out of the meat samples until the water-protein-STPP complex barrier formation on the surface of the meat samples was completed (Tenhet et al., 1991). Moreno et al. (2010) reported that MTGase is active and stable at a wide $\mathrm{pH}$ range of 4-9 and the optimum $\mathrm{pH}$ was at 5-8.

\section{$3.8 \operatorname{Colour}\left(L^{*} a^{*} b^{*}\right)$}

Table 3 shows that the colour ( $\mathrm{L}^{*} \mathrm{a}^{*}$ and $\mathrm{b}^{*}$ ) value for treated shrimp was significantly different from control $(p \leq 0.05)$. Treatments with MTGase increased a* value $(+=$ red) of treated shrimp, while treatments with STPP and $\mathrm{NaHCO}_{3}$ increased $\mathrm{b}^{*}$ value ( $+=$ yellow). The $\mathrm{a}^{*}$ and $\mathrm{b}^{*}$ values increased in treated shrimp due to the interaction of pigments with the food additives. Pietrasik and Li-Chan (2002) reported that MTGase addition had no significant influence on the $b^{*}$ value of restructured meat, the addition of $0.5 \%$ MTG increased lightness and redness of gels containing $8 \%$ meat protein and $2 \%$ egg albumin with $0.5 \%$ K-carrageenan, respectively. 
Table 3. Effects of three additives combination with $2 \% \mathrm{NaCl}$ on colour $\mathrm{L}^{*} \mathrm{a}^{*} \mathrm{~b} *$

\begin{tabular}{|c|c|c|c|c|c|c|}
\hline Treatment & $\begin{array}{c}\text { Level } \\
(\%)\end{array}$ & $\begin{array}{c}\text { Time } \\
(\text { mins })\end{array}$ & $\begin{array}{l}\text { Additives } \\
+2 \% \mathrm{NaCl}\end{array}$ & $\mathrm{L}^{*}$ & $a^{*}$ & $b^{*}$ \\
\hline Control & 0 & 0 & Un-treated & $51.67 \pm 2.01^{\mathrm{a}}$ & $-0.10 \pm 0.92^{\mathrm{de}}$ & $-3.55 \pm 1.42^{\text {bcdef }}$ \\
\hline 1 & 2 & 10 & MTGase & $46.98 \pm 1.24^{\text {bcde }}$ & $3.76 \pm 0.22^{\mathrm{ab}}$ & $-2.46 \pm 4.11^{\mathrm{abc}}$ \\
\hline 2 & 2 & 30 & MTGase & $47.42 \pm 1.09^{\mathrm{bcd}}$ & $4.35 \pm 2.06^{\mathrm{a}}$ & $-1.32 \pm 1.29^{\mathrm{ab}}$ \\
\hline 3 & 2 & 60 & MTGase & $46.16 \pm 0.99^{\text {bcdef }}$ & $3.95 \pm 1.32^{\mathrm{ab}}$ & $-1.35 \pm 2.12^{\mathrm{ab}}$ \\
\hline 4 & 5 & 10 & MTGase & $45.88 \pm 1.48^{\text {cdef }}$ & $4.04 \pm 1.28^{\mathrm{ab}}$ & $-2.97 \pm 2.03^{\text {abcde }}$ \\
\hline 5 & 5 & 30 & MTGase & $45.35 \pm 0.19^{\text {cdef }}$ & $5.41 \pm 3.68^{\mathrm{a}}$ & $-1.86 \pm 2.10^{\mathrm{abc}}$ \\
\hline 6 & 5 & 60 & MTGase & $46.65 \pm 1.46^{\text {bcdef }}$ & $4.79 \pm 2.85^{\mathrm{a}}$ & $-1.36 \pm 2.40^{\mathrm{ab}}$ \\
\hline 7 & 8 & 10 & MTGase & $46.25 \pm 1.40^{\text {bcdef }}$ & $4.23 \pm 1.65^{\mathrm{a}}$ & $-0.89 \pm 2.61^{a}$ \\
\hline 8 & 8 & 30 & MTGase & $47.45 \pm 0.86^{\mathrm{bcd}}$ & $4.94 \pm 1.65^{\mathrm{a}}$ & $-2.77 \pm 1.36^{\mathrm{abcd}}$ \\
\hline 9 & 8 & 60 & MTGase & $46.72 \pm 0.69^{\text {bcdef }}$ & $4.08 \pm 2.71^{\mathrm{ab}}$ & $-2.48 \pm 0.93^{a b c}$ \\
\hline 10 & 2 & 10 & $\mathrm{NaHCO}_{3}$ & $46.60 \pm 4.33^{\text {bcdef }}$ & $1.80 \pm 1.94^{\mathrm{cd}}$ & $-4.08 \pm 1.77^{\text {cdefg }}$ \\
\hline 11 & 2 & 30 & $\mathrm{NaHCO}_{3}$ & $46.41 \pm 4.25^{\text {bcdef }}$ & $0.49 \pm 1.17^{\mathrm{cde}}$ & $-5.60 \pm 3.20^{\text {fghijk }}$ \\
\hline 12 & 2 & 60 & $\mathrm{NaHCO}_{3}$ & $46.83 \pm 1.36^{\text {bcdef }}$ & $0.33 \pm 0.55^{\mathrm{de}}$ & $-6.10 \pm 2.43^{\text {ghijkl }}$ \\
\hline 13 & 5 & 10 & $\mathrm{NaHCO}_{3}$ & $45.98 \pm 1.54^{\text {cdef }}$ & $0.83 \pm 1.00^{\text {cde }}$ & $-5.36 \pm 1.48^{\text {fghij }}$ \\
\hline 14 & 5 & 30 & $\mathrm{NaHCO}_{3}$ & $44.73 \pm 3.51^{\mathrm{def}}$ & $1.30 \pm 2.16^{\mathrm{cde}}$ & $-7.72 \pm 1.12^{\mathrm{jkl}}$ \\
\hline 15 & 5 & 60 & $\mathrm{NaHCO}_{3}$ & $45.48 \pm 3.10^{\text {cdef }}$ & $0.73 \pm 1.76^{\mathrm{cde}}$ & $-7.59 \pm 1.66^{\mathrm{ijkl}}$ \\
\hline 16 & 8 & 10 & $\mathrm{NaHCO}_{3}$ & $43.59 \pm 1.96^{\mathrm{ef}}$ & $2.31 \pm 1.63^{b c}$ & $-6.55 \pm 2.75^{\text {ghijkl }}$ \\
\hline 17 & 8 & 30 & $\mathrm{NaHCO}_{3}$ & $44.87 \pm 2.83^{\mathrm{def}}$ & $0.92 \pm 1.29^{\text {cde }}$ & $-7.77 \pm 1.07^{\mathrm{jk} 1}$ \\
\hline 18 & 8 & 60 & $\mathrm{NaHCO}_{3}$ & $43.22 \pm 1.00^{f}$ & $1.04 \pm 1.60^{\mathrm{cde}}$ & $-8.07 \pm 1.12^{\mathrm{kl}}$ \\
\hline 19 & 2 & 10 & STPP & $47.88 \pm 1.21^{\mathrm{bcd}}$ & $-0.13 \pm 0.01^{\mathrm{de}}$ & $-5.61 \pm 0.81^{\text {fghijk }}$ \\
\hline 20 & 2 & 30 & STPP & $48.63 \pm 0.49^{\mathrm{abc}}$ & $-0.28 \pm 0.28^{\mathrm{e}}$ & $-5.17 \pm 0.13^{\text {fghi }}$ \\
\hline 21 & 2 & 60 & STPP & $49.81 \pm 2.68^{\mathrm{ab}}$ & $-0.47 \pm 0.52^{\mathrm{e}}$ & $-5.00 \pm 0.56^{\text {defgh }}$ \\
\hline 22 & 5 & 10 & STPP & $46.58 \pm 2.67^{\text {bcdef }}$ & $0.05 \pm 0.72^{\mathrm{de}}$ & $-6.17 \pm 2.79^{\text {ghijkl }}$ \\
\hline 23 & 5 & 30 & STPP & $46.40 \pm 2.18^{\text {bcdef }}$ & $0.96 \pm 1.22^{\mathrm{cde}}$ & $-6.06 \pm 2.96^{\text {ghijkl }}$ \\
\hline 24 & 5 & 60 & STPP & $46.00 \pm 0.13^{\text {cdef }}$ & $0.11 \pm 0.71^{\mathrm{de}}$ & $-8.12 \pm 1.14^{1}$ \\
\hline 25 & 8 & 10 & STPP & $44.38 \pm 0.69^{\mathrm{def}}$ & $0.49 \pm 1.33^{\mathrm{cde}}$ & $-6.60 \pm 2.86^{\text {hijkl }}$ \\
\hline 26 & 8 & 30 & STPP & $45.19 \pm 1.43^{\text {cdef }}$ & $0.23 \pm 0.95^{\mathrm{de}}$ & $-7.28 \pm 1.00^{\text {hijkl }}$ \\
\hline 27 & 8 & 60 & STPP & $44.76 \pm 3.70^{\mathrm{def}}$ & $0.23 \pm 1.11^{\mathrm{de}}$ & $-8.51 \pm 2.40^{1}$ \\
\hline
\end{tabular}

Means in the same column followed by the same letter are not significantly different $(\mathrm{p}>0.05)$.

Benjakul et al. (2008) reported that the $\mathrm{L}^{*} \mathrm{a}^{*} \mathrm{~b}^{*}$ value of white shrimp was increased when heating time was longer than 0.5 to 1 mins ( $>0.05)$.

\section{Discussion}

\subsection{Effect of $2 \% \mathrm{NaCl}$ combination with MTGase, STPP} and $\mathrm{NaHCO}_{3}$

When the frozen-thawed shrimp were submerged in the additives solution with $2 \% \mathrm{NaCl}$, water molecules started diffusing into the shrimp meat. The role of the $2 \% \mathrm{NaCl}$ was to enhance protein-water interaction. Part of the additives and $2 \% \mathrm{NaCl}$ molecule anchored to positively charged groups of proteins, while the rest scavenged for free water molecule and presumably created a gradient concentration to allow more water to propagate into shrimp muscle. Protein composition and conformation have significant effects on water holding capacity (WHC). Combination of $2 \% \mathrm{NaCl}$ with the three types of additives have a synergistic effect to enhance the WHC and significantly increased the weight gain, moisture content and reduced cooking loss $(\mathrm{p} \leq 0.05)$ (Tables 2 and 3$)$.
Shults and Wierbicki (1973) reported that the combination of $1-5 \%$ salt to $0.5 \%$ phosphates namely; tetrasodium pyrophosphate (TSPP), sodium tripolyphosphate (STPP) and sodium hexametaphosphate (SHMP) solution reduce the shrinkage of chicken breast after cooking and increased the water holding capacity compared to sample treated with phosphate without salt. Phosphate and salt were found to have a synergistic effect on reducing cooking loss. When WHC increased, the ionic strength was also increased which caused the swelling of muscle fibre and increased extractability and solubility of myofibrillar protein (Liu and Xiong, 1997).

Damodaran and Kinsella (1982) reported that salt increased the functional properties of protein due to hydrophobic and electrostatic interactions which resulted in thermal stability of proteins. Faithong et al. (2006) reported that the effect of $1-3 \%$ salt combination with $2 \%$ tetrasodium pyrophosphate (TSPP), sodium tripolyphosphate (STPP) and sodium hexametaphosphate (SHMP) on shear force was found to depend on salt concentration; the higher shear force value was with the shrimp immersed in a higher salt concentration. In cooked restructured meat, the water-holding capacity 
(WHC) was increased by the addition of $0.5 \%$ MTGase in high salt (2\%), but not in low salt products (Pietrasik and Li-Chan, 2002).

\subsection{Selection of suitable food additives for the pre- treatment}

The most suitable food additive that had been selected as the treatment was the MTGase (Activa ${ }^{\circledR}$ TG$\mathrm{HP})$ at $5 \%$ concentration with $2 \% \mathrm{NaCl}$ for 30 mins. Immersion white shrimp in 5\% MTGase with $2 \% \mathrm{NaCl}$ for 30 mins increased the WG (15.68\%), MC (84.00\%) and WHC (94.50\%), lowered CL to $10.15 \%$ and reduced TVC for about $1.44 \log$ CFU/g compared with control. The shear force value for this sample was not significantly different from control. Only the $\mathrm{pH}$ value of treated shrimp (5\% MTGase with $2 \% \mathrm{NaCl}$ for 30 mins) needed to be adjusted because the $\mathrm{pH}$ of treated shrimp was 9.30. If the beginning of $\mathrm{pH}$ value of marinated shrimp in green curry was higher the final $\mathrm{pH}$ of the product after storage will be too high. Dziezak (1990) reported that higher $\mathrm{pH}$ value will shorten the shelf-life of the product and failures as sliminess, translucency and fat decomposition will be observed.

The decision had been made to reduce the $\mathrm{pH}$ value of the treated shrimp before it was mixed with green curry. The raw shrimp was rinsed using running tap water before the pre-treatment with the 5\% MTGase and $2 \% \mathrm{NaCl}$ for $30 \mathrm{mins}$ at $4 \pm 2^{\circ} \mathrm{C}$. For the second step, after the pre-treated shrimp was drained, it was rinsed with water again for $30 \mathrm{~s}$ and drained before immersion in $0.5 \%$ citric acid for $5 \mathrm{mins}$ at $4 \pm 2^{\circ} \mathrm{C}$. After that, the treated shrimp was drained and mixed with green curry. The $\mathrm{pH}$ of the green curry was $5.10 \pm 0.03$.

Finally, the average $\mathrm{pH}$ value of $120 \mathrm{~g}$ marinated shrimp with green curry was 7.68 . This product was categorized as a low acid food, which is suitable to maintain a good quality of shrimp texture. Citric acid was certified as GRAS (Generally Recognized as Safe) status according to US FDA (Food and Drug Administration) and the maximum daily dosage limit is 8 grams (FDA, 2012).

Low acid food products are important for product like marinated shrimp in green curry to improve the quality of the shrimp by increasing the WHC, MC, WG and improve the texture. Xiong et al. (2002) reported that high acid food like marinated food in acidic solutions (citric acid, lemon juice) caused protein denaturation, resulting in decreased water binding ability of myosin, actin and other myofibrillar proteins. Prawns marinated in sodium tripolyphosphate solution $(\mathrm{pH} 7.0)$ did not show a significant change in muscle toughness. But immersion in calcium chloride $\left(\mathrm{CaCl}_{2}\right)$ at $\mathrm{pH}$ 7.0, citric acid $(\mathrm{pH} 3.0)$ and lemon juice $(\mathrm{pH} 3.0)$ increased $(\mathrm{p}<0.05)$ the muscle toughness of marinated prawn (Xiong et al., 2002).

\section{Conclusion}

Dipping frozen-thawed white shrimp in food additives was an important step to get a good quality of final process product. The treatments with nonphosphate additives can be an alternative way to improve the quality of frozen white shrimp. Overall, the treatments increased the WG (15.65\%), MC (84.00\%) and WHC $(94.50 \%)$, lowered CL to $10.15 \%$ and reduced TVC for about 1.78 log cycle. Immersion white shrimp in 5\% MTGase for 30 mins improved the quality when compared with control.

\section{Acknowledgements}

This scientific study was financed by the Graduate School Chulalongkorn University and Malaysian Agricultural Research Development Institute. We thank Charoean Pokphand Food Public Company and Ajinomoto Co. (Thailand) Ltd. for supporting the raw material for this project.

\section{References}

AOAC. (2005). Official Methods of Analysis. $18^{\text {th }} \mathrm{ed}$. Washington, DC: Association of the Official Analytical Chemists.

Benjakul, S., Visessanguan, W., Kijroongrojana, K. and Sriket, P. (2008). Effect of heating on physical properties and microstructure of black tiger shrimp (Penaueus monodon) and white shrimp (Penaeus vannamei) meats. International Journal of Food Science and Technology, 43(6),1066-1072. https:// doi.org/10.1111/j.1365-2621.2007.01566.x

Carballo, J., Ayo, J. and Jime'nez Colmenero, F. (2006). Microbial transglutaminase and caseinate as cold set binders: Influence of meat species and chilling storage. LWT-Food Science and Technology, 39(6), 692-699. https://doi.org/10.1016/j.lwt.2005.03.020

Damodaran, S. and Kinsella, J.E. (1982). Effects of ion on protein conformation and functionality. In Cherry, J.P. (Ed.) Food Protein Deterioration, Mechanism and Functionality, p. 327-358. Washington D.C: American Chemical Society. https://doi.org/10.1021/bk-1982-0206.ch013

Díaz-Tenorio, L.M., Garcia-Carreno, F.L. and PachecoAguilar, R. (2007). Comparison of freezing and thawing treatments on muscle properties of whiteleg shrimp (Litopanaeus vannamei). Journal of Food Biochemistry, 31(5), 563-576. https:// 
doi.org/10.1111/j.1745-4514.2007.00130.x

Dziezak, J.D. (1990). Phosphate improves many foods. Food Technology, 44, 80-92.

Erdogdu, S.B., Erdogdu, F. and Ekiz, H.I. (2007). Influence of sodium tripolyphosphate (STP) treatment and cooking time on cook losses and textural properties for red meats. Journal of Food Process Engineering, 30(6), 685-700. https:// doi.org/10.1111/j.1745-4530.2007.00139.x

Faithong, J., Raksakulthai, N. and Chaiyawat, M. (2006). Effect of phosphate and salt on yield and quality of cooked white shrimp (Penaeus vannamei). Kasetsart Journal (Natural Science), 40(Suppl.), 108-116.

FDA, U.S. Food and Drug Administration. (2012). Food and drugs. Retrieved on February 2013 from FDA website: http://www.accessdata.fda.gov/scripts/cdrh/ cfdocs/cfcfr/CFRSearch.cfm?fr=331.11

Gonçalves, A.A. and Ribeiro, J.L.D. (2008). Do phosphates improve the seafood quality? Reality and legislation. Pan-American Journal of Aquatic Sciences, 3(3), 237-247.

Henderson, N.R, Kaiser, A. and Montville, T.J. (1990). Use of bicarbonate dip to improve water binding capacity in fresh shrimp. Tropical and Subtropical Fisheries Technological Conference of the Americas, September 29 - October 3, 1991, p. 163-168. Raleigh, USA.

Liu, G. and Xiong, Y.L. (1997). Gelation of chicken muscle myofibrillar proteins treated with protease inhibitors and phosphates. Journal of Food Agriculture and Chemistry, 45(9), 3437-3442. https://doi.org/10.1021/jf9700485

Mallick, A.K., Srinivasa Gopal, T.K., Ravishankar, C.N., Vijayan, P.K. and Geethalakshmi, V. (2010). Changes in instrumental and sensory properties of Indian white shrimp in curry medium during retort pouch processing at different $\mathrm{F}_{\mathrm{o}}$ Values. Journal of Texture Studies, 41(5), 611-632. https:// doi.org/10.1111/j.1745-4603.2010.00243.x

McLandsborough, L. (2005). Food Microbiology Laboratory, p. $1-6$. Washington, DC.: CRC Press

Mizuta, S., Yamada, Y., Miyagi, T. and Yoshinaka, R. (1999). Histological changes in collagen related to textural development of prawn meat during heat processing. Journal of Food Science, 64(6), 991995.

2621.1999.tb12266.x

Moreno, H.M., Carballo, J. and Borderías, J. (2010). Gelation of fish muscle using microbial transglutaminase and the effect of sodium chloride and pH levels. Journal of Muscle Foods, 21(3), 433450.

https://doi.org/10.1111/j.1745-

4573.2009.00193.x
Motoki, M. and Seguro, K. (1998). Transglutaminase and its use for food processing. Trends in Food Science and Technology, 9(5), 204-210. https:// doi.org/10.1016/S0924-2244(98)00038-7

Pietrasik, Z. and Li-Chan, E.C.Y. (2002). Binding and textural properties of beef gels as affected by protein K-Carrageenan and microbial transglutaminase addition. Food Research International, 35(1), 91-98. https://doi.org/10.1016/S0963-9969(01)00123-5

Schubring, R., Meyer, C., Schluter, O., Boguslawski, S. and Knorr, D. (2003). Impact of high pressure assisted thawing on the quality of fillets from various fish species. Journal of Innovative Food Science and Emerging Technologies, 4(3), 257-267. https:// doi.org/10.1016/S1466-8564(03)00036-5

Shults, G.W. and Wierbicki. E. (1973). Effect of sodium chloride and condensed phosphates on the water holding capacity, $\mathrm{pH}$ and swelling of chicken muscle. Journal of Food Science, 38(6), 991-994. https://doi.org/10.1111/j.1365-2621.1973.tb02131.x

Sriket, P., Benjakul, S., Visessanguan, W. and Kijroongrojana, K. (2007). Comparative studies on chemical composition and thermal properties of black tiger shrimp (Penaeus monodon) and white shrimp (Penaeus vannamei) meats. Food Chemistry, 103(4), 1199-1207. https://doi.org/10.1016/ j.foodchem.2006.10.039

Siripongvutikorn, S., Pengseng, N., Ayusuk, S. and Usawakesmanee, W. (2008). Development of green curry paste marinade for white shrimp (Litopenaeus vannamei). Songklanakarin Journal of Science and Technology, 30, 35-40.

Tammatinnaa, A., Benjakula, S., Visessanguanb, W. and Tanaka, M. (2007). Gelling properties of white shrimp (Penaeus vannamei) meat as influenced by setting condition and microbial transglutaminase. LWT - Food Science and Technology, 40(9), 14891497. https://doi.org/10.1016/j.lwt.2006.11.017

Tenhet, V., Finne, G., Nickelson, R. and Toloday, D. (1981). Phosphorus level in peeled and deveined shrimp treated with sodium tripolyphosphate. Journal of Food Science, 46(2), 350-352.

Ünal, S.B., Erdogdu, F., Ekiz, H.I. and Ozdemir, Y. (2004). Experimental theory, fundamentals and mathematical evaluation of phosphate diffusion in meats. Journal of Food Engineering, 65(2), 263272. https://doi.org/10.1016/j.jfoodeng.2004.01.024

Xiong, S., Xiong, Y.L., Blachard, S.P, Wang, B. and Tidwell, H.J. (2002). Evaluation of tenderness in prawns (Machrobrachium rosenbergi) marinated in various salt and acid solutions. International Journal of Food Science and Technology, 37(3), 291-296. https://doi.org/10.1046/j.1365-2621.2002.00569.x 